\title{
Traditional Food Security "Urutan" Special Bali Based on Chicken Meat is Reviewed from Microbial Contamination
}

\author{
IW. Sudiarta ${ }^{1}$, AAM. Semariyani $^{2}$, IP. Candra ${ }^{3}$, NM. Darmadi ${ }^{4}$, DGS. Edi ${ }^{5}$ \\ \{sudiartaiwayan67@gmail.com ${ }^{1}$, semariyanimega1965@gmail.com² ${ }^{2}$ candra_atsiribali@yahoo.co.id ${ }^{3}$, \\ nimadedarmadi210466@gmail.com ${ }^{4}$, semaraedi@gmail.com $\left.{ }^{5}\right\}$ \\ Program Studi Ilmu dan Teknologi Pangan, Fakultas Pertanian, Universitas \\ Warmadewa, Denpasar, Bali ${ }^{12345}$
}

\begin{abstract}
This study aims to determine the presence or absence of microbial contamination in the chicken of "urutan" in an effort to ensure the quality and safety of food "urutan" for consumers. This research was conducted from May to September 2018 at the Processing Laboratory in the Faculty of Agriculture, Warmadewa University and the Microbial Test carried out at the Veterinary Laboratory, Denpasar. The method used in achieving the goal is to make the "urutan" of chicken with the best formulation from previous studies, namely the formulation of $10 \%$ fat addition without fermentation treatment then performed microbial contamination testing on the "urutan " of chicken produced. From the test results will be known whether the "urutan" safe or not consumed after compared with meat sausage quality standards (SNI 01-3820-2015) especially from microbial contamination. Test results for chicken meat as raw material "urutan" of parameters Total Plate Count obtained $1.0 \times 10^{6}$ colonies / gram, Coliform $<1 \times 10^{2}$ colonies / gram, E. coli $<3.6$ colonies / gram, Staphilococcus aureus $<10$ colonies / gram and Salmonella are negative, all of them meet the standards of fresh meat [1]. While the test results for the "urutan" of raw, steamed, fried and "urutan" chicken stored in oil for up to 21 days of storage still meet the requirements set by SNI 01-3820-2015, except for some TPC and Coliform that are above the threshold the required limit, but when viewed from the preparation process "urutan" to be consumed, the frying process is always carried out so that it can eliminate the microbial contamination, so that the "urutan" of the chicken is still safe to be consumed until storage for 21 days in frying oil.
\end{abstract}

Keywords: chicken of "urutan", food security, traditional food.

\section{Introduction}

The "urutan" is analog sausage food products that are traditionally made in Bali through fermentation and non-fermentation. "Urutan" is usually done on Galungan holidays, where people cut pigs for ceremonial purposes, so there is a lot of meat available. The community seeks to extend the shelf life of the meat by processing it into food products that can be stored for longer. There are two ways that are commonly done by Balinese people, namely by drying it into jerky and by fermentation into "urutan", bebontot, brengkes, buntilan and takilan boar (Antara et al., 2002, Partama et al., 2005; Nocianitri, 2009).

In general, the "urutan" is made of meat and lard, salt and spices (Pepper, red chili, coriander, ginger and galingale) with or without added sugar, using pig intestine sheaths, dried in the sun for three to five days, then stored at room temperature, resulting in a natural fermentation process [2]. But now the "urutan" has been made commercially and traded both 
in traditional markets and modern markets. To meet consumer tastes, market demands and diversification of food, the raw materials used are no longer from pork, but now in the market order made from chicken meat, this is especially intended for consumers who do not consume pork or who are allergic to meat pigs, and casings or casings used in the form of edible films.

As a traditional food that is still very popular with Balinese people and has begun to attract domestic and foreign tourists, the quality and safety of the "urutan" of chicken is not widely known. For this reason, research is needed to find the right formulation in "urutan" to obtain a "urutan" of chicken with good characteristics and be liked by consumers. So that people who want to make the "urutan" of chicken as souvenirs, believe that the "urutan" of chicken is safe for consumption and has guaranteed quality. The results of the study are expected to provide information on the proper formulation, nutrient content and traditional food safety of "urutan" of chicken in an effort to improve the quality of "urutan" of chicken and traditional food security.

Formulation of the problem, traditionally, the urutan-making process made without or fermented only relies on very simple equipment and methods (commonly used kitchen equipment such as cutting boards, knives, seasoning spices, cooker frying pan etc.) so that food quality and safety the traditional results are very dependent on environmental factors and the health of the person working on it. With the increasing interest of traditional food by the people, it is necessary to find the right formulation in order to obtain a "urutan" of chicken with good characteristics and preferred by consumers. In addition, it is also necessary to know food safety from traditional "urutan" of chicken so that people can safely consume "urutan" of chicken Safe food is a demand of consumers and will compete in the global market. If producers are unable to meet food safety requirements, this will be an obstacle in competing to expand the food export market.

The suitability of traditional food products with quality standards is also a consideration in determining policies to prevent irregularities in controlling the quality of traditional food products in the "urutan" of chicken. This is to prevent claims from fans of traditional "urutan" of chicken foods. With the convenience of traditional culinary consumers on the quality of food products, it will indirectly protect consumers from consuming traditional "urutan" of chicken foods. So that it will be able to stimulate producers to further increase the production of traditional "urutan" of chicken. In terms of the economy, this will make transactions healthy, because it can provide business certainty and can facilitate the marketing process of traditional chicken orders. Hopefully in the future, traditional food culinary "urutan" of chicken can become part of entrepreneurship for the community, to reduce the high unemployment rate.

Based on the foregoing, it is necessary to conduct research on Traditional Balinese Food Safety Urutan of Chicken Meat from Microbial Contaminants in order to obtain certainty for consumers to obtain "urutan" of chicken with good characteristics, preferred and safe for consumers.

\section{Research Methods}

\subsection{Location and Time of Research}

Research (making "urutan" of chicken) was carried out at the Laboratory of the Faculty of Agriculture, Warmadewa University in Denpasar. Testing samples and observations carried out at the Laboratory of the Veterinary Center of the Ministry of Agriculture, Directorate 
General of Animal Husbandry and Animal Health in Denpasar. The time of research begins in May-November 2018.

\subsection{Research methodology}

The initial stage was carried out in the process of making "urutan" of chicken with the best treatment from the first phase of the study, which was the addition of $10 \%$ fat without fermentation treatment. After that followed by microbiological testing (ALT test / Total Plate Number, Coliform bacteria, Escherichia coli, Salmonella, Staphylococcus aureus (SNI 013820-2015).

\subsection{Material}

The materials used in this study were sequential samples from the best results from the first phase of research, namely the addition of $10 \%$ fat without fermentation, $70 \%$ alcohol, distilled water, crystal violet solution, iodine solution, safranin dye, spritus, Brilliant Green Lactose Broth Bile (BGLB), Laktose Broth (LB), Bismuth Sulfite Agar (BSA), Buffered Pepton Water (BPW), Eosin Methylene Blue (EMB), Luria Broth (LB),Manitolt Salt Agar (MSA), Pepton Water (PW), Selenite Cystine Broth (SCB),Trypticase Soy Agar (TSA) dan Triple Sugar Iron Agar (TSIA).

\subsection{Implementation phase}

Activities at the implementation stage are as follows:

1) Make "urutan" of chicken by treating $10 \%$ fat without fermentation

2) Perform microbiological testing or analysis of chicken meat, "urutan" of raw chicken, "urutan" of fried chicken, "urutan" of chicken that has been fried and soaked in oil used for frying stored for 5 days, 10 days and 15 days in the laboratory.

\subsection{Microbiology Analysis}

\section{a. Determination of ALT (Total Plate Number)}

Samples from dilutions of 10-3 and 10-4 were taken as much as $1 \mathrm{ml}$ and included in a petri dish containing Plate Count Agar media. Then the samples and media in the petri dish are homogenized and left to freeze. After freezing the petri dish was incubated for 24-48 hours at $37^{\circ} \mathrm{C}$. All colonies that appear on the media are expressed as the total number of bacteria in the sample $\mathrm{ml}$. Then calculated the average number of colonies in the petri dish with the dilution factor used. 


\section{b. Determination of Bacteria Salmonella [3]}

a. Pre-enrichment

A sample of $25 \mathrm{~g}$, was put into a $250 \mathrm{ml}$ Erlenmeyer and added an LB enrichment agent of $225 \mathrm{ml}$, then homogenized. After that, it was incubated at $37{ }^{\circ} \mathrm{C}$ for 24 hours.

b. Enrichment

Samples that were incubated for 24 hours at the pre-enrichment stage were then taken as much as $10 \mathrm{ml}$ and put into Erlenmeyer containing $100 \mathrm{ml}$ of Selenite Cystine Broth (SCB). After that, it was incubated for 24 hours at $37^{\circ} \mathrm{C}$.

c. Estimation Test

The enriched sample was taken 1 ose, then zigzagged onto the surface of Bismuth Sulfite Agar (BSA) media. After that the media was incubated for 24 hours at $37^{\circ} \mathrm{C}$. If there is unexpected Salmonella it will appear blackish brown to metallic luster that grows on the zig zag strokes. If unexpected, then to ensure that the suspected bacteria that grow is Salmonella, further testing is necessary.

d. Affirmation Test

Confirmation tests were carried out when blackish brown colonies to metallic luster appeared on selective Bismuth Sulfite Agar (BSA) media. The further test was carried out by taking 1 ose of Salmonella on the BSA media and then transferring it to the sloping NA media. Then incubated for 24 hours at $37^{\circ} \mathrm{C}$. The growing colonies were taken and inserted into the media Triple Sugar Iron Agar (TSIA) upright. Then incubated for 48 hours at $37{ }^{\circ} \mathrm{C}$.

\section{c. Determination of Bacteria Coliform}

a. Suspected Test

Samples from dilutions of 10-1, 10-2 and 10-3 were taken in $1 \mathrm{ml}$ and put in 3 tubes containing $5 \mathrm{ml}$ of Lactose Broth (LB) in which there was a reverse Durham tube. Then all the tubes are stored in the incubator at $37{ }^{\circ} \mathrm{C}$ for 48 hours. After 48 hours, the number of tubes forming gas in each dilution is recorded.

b. Affirmation Test

Each tube from the alleged test that forms a gas is taken 1 ose and transferred to a test tube containing the Briliant Green Lactose Broth media in which there is a reverse Durham tube. Then all the tubes are stored in the incubator at $37{ }^{\circ} \mathrm{C}$ for 48 hours. The test is positive if gas or bubbles are formed in the Durham tube. Note the number of tubes formed by gas in the affirmation test, then adjust to the MPN table [3].

\section{d. Determination of Bacteria Escherichia coli}

a. Suspected Test

The positive tube on the suspected Coliform bacteria test was taken 1 ose and put into a test tube containing $9 \mathrm{ml}$ of Luria Broth (LB) media in which there was a reverse Durham tube. The number of test tubes used for the test of suspected Escherechia coli bacteria, adjusted for the number of positive tubes contained in the suspected Coliform bacteria test. Then the test tube was incubated at $37^{\circ} \mathrm{C}$ for $24-48$ hours. The number of tubes formed by gas is recorded and adjusted to the MPN table [3].

b. Affirmation Test

The suspected test tube containing $E$. coli (if gas was formed) was chosen and taken 1 ose then inoculated by zigzagging into a petri dish containing Eosin Methylene Blue 
(EMB) which had been frozen. Biakan incubated at 37 padaC for 24 hours. A positive test for the presence of E. coli is characterized by metallic luster colonies on EMB media.

\section{e. Determination of Bacteria Staphylococcus aureus [3]}

a. Suspected Test

Samples from $10^{3}$ and 104 dilutions were taken as much as $1 \mathrm{ml}$ and included in a petri dish. Then the cooled Trypticase Soy Agar media is poured into the petri dish. The sample and media are homogenized and left to freeze. Then the petri dishes were incubated at $37^{\circ} \mathrm{C}$ for $24-48$ hours. If a bacterial colony is formed, then it is followed by an affirmation test.

b. Affirmation Test

The suspected colonies on the petri dish were taken, then scratched on a petri dish containing Mannitol Salt Agar media which had been frozen. Then the petri dishes were incubated at $37^{\circ} \mathrm{C}$ for $24-48$ hours. The test is positive if the color of the media changes from red to yellow.

\subsection{Data analysis}

The data obtained were analyzed descriptively with Tables or Figures and compared with the Indonesian National Standard of Meat Sausages (SNI 01-3820-2015).

\section{Result and Discussion}

\subsection{Result}

Observations of food safety indicator bacteria for "urutan" of chicken were observed according to quality standards according to SNI 01-3820-2015, which included total plate numbers (ALT), Coliform bacteria, Eschericia coli, Streptococcus aureus and Salmonella bacteria. Microbiological observations were carried out thoroughly including raw materials for chicken used, raw "urutan" of chicken made in the laboratory, "urutan" of steamed chicken, "urutan" of fried chicken, "urutan" of raw chicken sold in the market, "urutan" of chicken sold in the market that had been fried then the order that has been fried during storage is immersed in oil both made in the laboratory and taken from the market.

The results of observations on indicator bacteria / bacterial contamination found in "urutan" of chicken and chicken meat used as raw materials and stored at room temperature $28^{\circ} \mathrm{C}-30^{\circ} \mathrm{C}$ can be seen in Table 1 . 
Table 1. Observation results on average Total Plate Count (TPC), and MPN values of Coliform bacteria, E. Coli, S. Aureus and Salmonella in Chicken Meat and "urutan" of chicken

\begin{tabular}{|c|c|c|c|c|c|}
\hline \multirow[t]{2}{*}{ Sample } & \multicolumn{5}{|c|}{ Microbial contamination } \\
\hline & $\begin{array}{l}\text { TPC } \\
\text { (Koloni/g) }\end{array}$ & $\begin{array}{l}\text { Coliform } \\
\text { (MPN/g) }\end{array}$ & $\begin{array}{l}\text { E. coli } \\
(\mathrm{MPN} / \mathrm{g})\end{array}$ & $\begin{array}{l}\text { S.aureus } \\
\text { (koloni/g) }\end{array}$ & $\begin{array}{l}\text { Salmonella Sp. } \\
\text { (koloni/g) }\end{array}$ \\
\hline Chicken meat & $1,0 \times 10^{6}$ & $>1.100$ & $<3$ & $<10$ & Negatif \\
\hline $\begin{array}{l}\text { "Urutan" of } \\
\text { raw chicken }\end{array}$ & $1,1 \times 10^{6}$ & $>1.100$ & $<3$ & $<10$ & Negatif \\
\hline $\begin{array}{l}\text { "Urutan" } \\
\text { steamed } \\
\text { chicken }\end{array}$ & $1,4 \times 10^{6}$ & 240 & $<3$ & $<10$ & Negatif \\
\hline $\begin{array}{l}\text { "Urutan" of } \\
\text { fried chicken } \\
\text { "Urutan" of }\end{array}$ & $3,4 \times 10^{3}$ & 9,2 & $<3$ & $<10$ & Negatif \\
\hline $\begin{array}{l}\text { raw chicken } \\
\text { on the market }\end{array}$ & $2,7 \times 10^{5}$ & 9,2 & $<3$ & $<10$ & Negatif \\
\hline $\begin{array}{l}\text { "Urutan" of } \\
\text { fried chicken } \\
\text { on the market }\end{array}$ & $1,9 \times 10^{4}$ & 23 & $<3$ & $<10$ & Negatif \\
\hline
\end{tabular}

Testing of the microbiological parameters of bacterial food safety indicators in the "urutan" was carried out using selective growth media. The presence of Coliform bacteria, E. coli, S. aureus and Salmonella $s p$ in growth media is characterized by different characteristics of the media used. From the results of the observations it has been proven that chicken as the raw material for the "urutan" of chicken and all sample of "urutan" that are both raw and fried positively contain Coliform bacteria, E. coli and $S$. aureus shortly after being handled or processed into "urutan" of chicken. TPC chicken meat that is used as raw "urutan" raw material for chicken and steamed on average contains higher TPC compared to "urutan" of fried chicken both made in the laboratory and "urutan" of chicken sold in the market.

Coliform MPN values in chicken meat samples, raw and steamed chicken "urutan" turned out to exceed the standards set by SNI 01-3820-2015 which is a maximum of 10. Coliform content from observations on chicken meat and "urutan" were raw $>1,100 \mathrm{MPN} / \mathrm{g}$ while the "urutan" of steamed chicken is $240 \mathrm{MPN} / \mathrm{g}$. Whereas S.aureus contamination is stated to be in accordance with these standards.

The observations also prove that the "urutan" of chickens made in the laboratory and "urutan" of chicken purchased on the market which are then stored at room temperature $\left(28^{\circ} \mathrm{C}\right.$ $-30^{\circ} \mathrm{C}$ ) and soaked in frying oil are detected to contain Coliform bacteria, E.coli and S. aureus, while the content of Salmonella $s p$ was negative. Coliform content is stated to exceed the quality requirements and the content of $E$. coli and $S$. aureus is stated to meet the quality requirements according to SNI 01-3820-2015. Judging from the TPC content, it appears that TPC has increased during storage for up to 21 days in the "urutan" of chickens both made in the laboratory and sold on the market (Table 2). 
Table 2. Observations of TPC, Coliform bacteria, E. coli, S. aureus and Salmonella sp "urutan" of chicken During Storage

\begin{tabular}{|c|c|c|c|c|}
\hline $\begin{array}{l}\text { Microbial } \\
\text { contamination }\end{array}$ & $\begin{array}{l}\text { Duration of } \\
\text { storage }\end{array}$ & $\begin{array}{l}\text { sample } \\
\text { "urutan" of } \\
\text { chicken } \\
\text { results of } \\
\text { research }\end{array}$ & $\begin{array}{l}\text { "urutan" of } \\
\text { Chicken } \\
\text { sold on the } \\
\text { market }\end{array}$ & $\begin{array}{l}\text { Quality Requirements for Meat } \\
\text { Sausages } \\
\text { SNI 01-3820-2015 }\end{array}$ \\
\hline ТPC & $\begin{array}{l}\text { H0 (0 days) } \\
\text { H1 (7 days) } \\
\text { H2 (14 days) } \\
\text { H3 (21 days) }\end{array}$ & $\begin{array}{l}3,4 \times 10^{3} \\
2,0 \times 10^{5} \\
2,4 \times 10^{5} \\
1,6 \times 10^{8}\end{array}$ & $\begin{array}{l}1,9 \times 10^{4} \\
1,2 \times 10^{5} \\
4,7 \times 10^{5} \\
2,2 \times 10^{8}\end{array}$ & $\operatorname{Max} 10^{3}$ \\
\hline Coliform & $\begin{array}{l}\text { H0 (0 days) } \\
\text { H1 ( } 7 \text { days) } \\
\text { H2 (14 days) } \\
\text { H3 (21 days) }\end{array}$ & $\begin{array}{l}9,2 \\
23 \\
>1.100 \\
>1.100\end{array}$ & $\begin{array}{l}23 \\
240 \\
>1.100 \\
>1.100\end{array}$ & Max 10 \\
\hline E. coli & $\begin{array}{l}\text { H0 (0 days) } \\
\text { H1 ( } 7 \text { days) } \\
\text { H2 (14 days) } \\
\text { H3 (21 hari }\end{array}$ & $\begin{array}{l}<3 \\
<3 \\
<3 \\
<3\end{array}$ & $\begin{array}{l}<3 \\
<3 \\
<3 \\
<3\end{array}$ & $<3$ \\
\hline $\begin{array}{l}\text { Streptococcus } \\
\text { aureus }\end{array}$ & $\begin{array}{l}\text { H0 (0 days) } \\
\text { H1 ( } 7 \text { days) } \\
\text { H2 (14 days) } \\
\text { H3 ( } 21 \text { days })\end{array}$ & $\begin{array}{l}<10 \\
<10 \\
<10 \\
<10\end{array}$ & $\begin{array}{l}<10 \\
<10 \\
<10 \\
<10\end{array}$ & $\operatorname{Max} 10^{2}$ \\
\hline Salmonella & $\begin{array}{l}\text { H0 (0 days) } \\
\text { H1 ( } 7 \text { days) } \\
\text { H2 (14 days) } \\
\text { H3 ( } 21 \text { days) }\end{array}$ & $\begin{array}{l}\text { Neg } \\
\text { Neg } \\
\text { Neg } \\
\text { Neg }\end{array}$ & $\begin{array}{l}\text { Neg } \\
\text { Neg } \\
\text { Neg } \\
\text { Neg }\end{array}$ & Neg \\
\hline
\end{tabular}

\subsection{Discussion}

"Urutan" is one of the traditional Balinese specialties that is very popular. These traditional food products include the categories of fermented sausages we know. Sausage as a frozen food product, should be stored in a cooler with a temperature of $-18^{\circ} \mathrm{C}$. Pelczar (1986) states that storing food at freezing temperatures actually only inhibits the process of growth of bacteria that causes decay and damage, but does not kill bacterial cells. These bacterial cells can grow back like normal cells if they are in the appropriate environmental conditions for their growth. However, for preservation and storage of products, the "urutan" is generally not stored in cold temperatures but is stored traditionally by frying them and then soaked in oil which is used for frying for several days and each time the "urutan" is fried then cooked again. Antara (2004) [4] states that fermented urutan of pork have a shelf life of 14 days while those without fermentation and soaked in oil used for frying have a shelf life of 10 days. This is what underlies microbiological observations "urutan" of chicken carried out for 21 days to determine the food safety level of this "urutan" of chicken from its microbiological aspects.

The results of research on chicken meat as raw material for "urutan" of chicken for TPC have met the maximum requirements for microbial contamination in accordance with the Sausage Quality Requirements of SNI 01-3820-2015 which is 1.0 x $10^{6}$ colonies / g, as well as 
the content of E.coli, S.aureus and Salmonella sp. also fulfills the requirements (Table 1). whereas after being processed into a sequence of raw and steamed TPC chicken, each TPC was increased to $1.1 \times 106$ colonies / g and 1.4 x 106 colony / g, positively containing the bacteria S. aureus, Salmonella, E. coli and Coliform $>1,100 \mathrm{MPN} / \mathrm{g}$ because it is characterized by the formation of gas in a durham tube in a test tube containing LB and BGLB test media. and decreased after the "urutan" of chicken was steamed or fried to $9.2 \mathrm{MPN} / \mathrm{g}$. After being fried with TPC, Coliform, E. coli, S. aureus and Salmonella sp. has fulfilled the Meat Sausage Quality Requirements SNI 01-3820-2015. Microbiological quality of processed meat into sausage products is largely determined by the quality of the raw materials of meat used, especially the presence of microbial contaminants in the form of pathogenic bacteria. Chicken meat is easily damaged by microbes, this is because the nutritional content contained in meat in addition to good for humans can also be used by microbes as a source of nutrition for growth and breeding. Processing is a way to prevent damage to chicken meat caused by bacteria. But in reality, the process of fresh meat processing can be a way for the entry of bacteria so that it can increase the number of pre-existing bacteria. The source of bacterial contamination in chicken meat and its processed products can come from the environment, workers, raw materials and seasonings (Volk and Wheeler, 1990). The total population will continue to increase during the time span processed until the sausage is stored [5]. The method of storage greatly determines the number of microbial populations contained in meat sausage products. According to Tirtana (2007) [6], most bacteria cannot survive in high salinity (hypertonic) environments. However, the genus Staphylococcus can adapt to high saline environments and grow well in meat sausages. Furthermore Suparno (1994) [5] states that chicken sausage contains $2 \%$ salt, equivalent to 2 grams per $100 \mathrm{~g}$ of sausage. In addition to containing chicken salt also added traditional spices which can also act as antimicrobial ingredients [7]. The results of microbiological tests on the order of chickens sold on the ground indicate that both the order of chicken which is raw and fried has fulfilled the requirements for the quality of meat sausages SNI 01-3820-2015.

Based on the results of the study (Table 2) in the storage "urutan" of chicken with soaking in oil on the 7th day there was an increase in TPC content in the "urutan" of chicken made in the laboratory, from $3.4 \times 10^{3}$ colonies $/ g$ to $2.0 \times 10^{5}$ colonies $/ g$. Likewise, the "urutan" of chicken sold on the market also experienced an increase in TPC content at 7 days storage, from $1.9 \times 10^{4}$ colonies / g to $1.2 \times 10^{5}$ colonies / g. Likewise, after being stored in oil until the 21 st day it continues to experience an increase in TPC, which is $1.6 \times 10^{8}$ Colonies / $\mathrm{g}$ for the "urutan" of chicken made in the laboratory and $2.2 \times 10^{8}$ colonies / $\mathrm{g}$ for "urutan" of chicken the sample is taken on the market. Kartika et al. (2014) [8] stated that the growth of total bacterial contamination occurred on the PCA media surface because total bacteria were aerobic. The total bacterial colonies that grow on PCA media are round to irregular, yellowish white with a slippery surface. In addition, these bacteria can grow at temperatures between $15^{\circ} \mathrm{C}-55^{\circ} \mathrm{C}$ with an optimum temperature of $25^{\circ} \mathrm{C}-40^{\circ} \mathrm{C}$ in foodstuffs. This is what causes bacteria to grow in chicken samples because it is also stored at room temperature, $28^{\circ} \mathrm{C}-30^{\circ} \mathrm{C}$. If the number of TPC "urutan" of chicken from the two types of samples is compared with the meat Sausage Quality Requirements SNI 01-3820-2015 which requires a maximum TPC of 103 samples. The "urutan" of the chicken is less than the TPC content. However, when viewed from the process of preparing the "urutan" to be consumed, usually by frying again the product "urutan" until cooked, then all the microbes in the urutan will die. Bacteria in chicken sausage, the growth temperature is only at temperatures of $15^{\circ} \mathrm{C}-55^{\circ} \mathrm{C}$, including mesophyll microbes which do not hold up at high temperatures. Thus, to be consumed if the order has been fried ripe, then it is still safe to consume until the order has been stored for 21 days. 
In Table 2 it can also be seen that in the "urutan" of chicken positive Coliform bacteria were detected, the initial amount of which was only 9.2 MPN / g in the "urutan" of chicken made in the laboratory increased to $>1,100 \mathrm{MPN} / \mathrm{g}$ at the $21 \mathrm{st}$ day storage. chickens whose samples are taken in the positive market contain Coliform bacteria, which has a bacterial content on day 0 only $23 \mathrm{MPN} / \mathrm{g}$ to $>1,100$ on day 21 . When compared to the meat Sausage Quality Requirements SNI 01-3820-2015 is required the number of Coliform bacteria is maximum of $10 \mathrm{MPN} / \mathrm{g}$ so that the "urutan" of chicken made in the laboratory and the "urutan" of chickens for which samples were taken from the market have not met the specified quality requirements. Some studies also prove that the presence of this bacterial contamination in sausages sold in traditional markets that positively contain Coliform with its MPN value exceeds SNI. Among them are Djoepri's research (2006), which found as many as 23 sausage samples taken from traditional markets positively containing Coliform bacteria. However, if we look at the order of preparation for consumption, which is usually cooked with deep fried, the coliform bacteria content in the "urutan" of chicken can be suppressed / destroyed. According to Kartika et al. (2014) [8] cooking at a temperature of $60^{\circ} \mathrm{C}-70^{\circ} \mathrm{C}$ in food ingredients can destroy Coliform bacteria because these bacteria include bacteria that are not resistant to heat. Thus, the order of chicken soaked in oil after being cooked by frying until cooked is still safe to consume until the 21 st day storage.

Tests on bacterial microbiological parameters of food safety indicators in "urutan" of chicken were also carried out on E. coli, S. aureus and Salmonella sp. The results of observations on the "urutan" samples made in the laboratory and samples taken on the market showed that there was a positive detection of contaminating bacteria $E$. coli and $S$. aureus while Salmonella $s p$. negative with $E$. coli content from day 0 to day 21 detected still $<3 \mathrm{MPN}$ / g, S.aureus $<10$ colonies / g and Salmonella sp. not detected. When compared with the SNI Sausage Quality Requirements of SNI 01-3820-2015, the content of the three types of bacterial indicators found in the "urutan" of chicken has met the requirements with maximum E. coli content $<3 \mathrm{MPN} / \mathrm{g}$, S.aureus maximum of 102 Colonies / g and Salmonella sp. must be negative. Thus, judging from the maximum requirements of the content of the three indicator bacteria, the "urutan" of chickens made in the laboratory and samples taken on the market have met the quality requirements specified in the Meat Sausage Quality Requirements SNI 01-3820-2015. Prevention of contamination by pathogenic bacteria can be done by handling food with the correct cooking process, preventing cross contamination and the application of personal hygiene and adequate sanitation. The cooking process with a temperature of $60^{\circ} \mathrm{C}-70^{\circ} \mathrm{C}$ can kill E. coli and Salmonella sp. [8]. Vegetative cells of S.aureus can be activated at temperatures $>46^{\circ} \mathrm{C}$ but the spores are still able to survive on heating at temperatures of $100^{\circ} \mathrm{C}-120^{\circ} \mathrm{C}$. Besides that enterotoxin toxins produced by S.aureus are resistant to high temperatures even though these bacteria die by heating but the toxins produced will not be damaged and can still survive even with cooling or freezing. Most bacterial spores can be damaged by heating $100^{\circ} \mathrm{C}$ for 30 minutes, but all bacterial spores will die at $121^{\circ} \mathrm{C}$ for 15 minutes [9]. 


\section{Conclusion}

Based on the results of research on food safety indicator bacteria in accordance with those specified in the meat Sausage quality requirements SNI 01-3820-2015. Then it can be concluded as follows:

4.1 Coliform pollutants, Escherichia coli and Streptococcus aureus were found while Salmonella $s p$ bacteria were not detected in the "urutan" of chicken sample. Coliform was detected $>1,100 \mathrm{MPN} / \mathrm{g}$ exceeding the maximum limit required in SNI, E. Coli was detected $<3 \mathrm{MPN} / \mathrm{g}$ according to the requirements, S. aureus was detected $<10$ colonies / $\mathrm{g}$ below the required maximum limit of $10^{2}$ colonies / $\mathrm{g}$.

4.2 Taking to account the quality requirements that have been set, the "urutan" of chicken soaked in oil is still categorized as safe from microbiological contamination and is still suitable for consumption up to 21 days of storage

\section{References}

[1] Badan Standarisasi Nasional.: Standar Nasional Indonesia (SNI) 7388-2009. Tentang Batas Maksimum Cemaran Mikroba Dalam Pangan. Jakarta (2009)

[2] Aryanta, W.: Utilization of Lactic Acid Bacteria to Improve the Quality of Balinese Traditional Fermented Sausage. Characteristics of Balinese Traditional Fermented Sausage. International Center of Biotechnology Osaka University, Japan. pp. 610-616 (2000)

[3] Badan Standarisasi Nasional. Standar Nasional Indonesia (SNI) 19-2897-1992. Tentang Cara Uji Cemaran Mikroba. Jakarta (1992)

[4] Antara, N.: Peranan Bakteri Penghasil Bakteriosin dalam Fermentasi urutan. Seminar Nasional Probiotik dan Prebiotik sebagai makanan Fungsional 30 Agustus 2004. Indonesian Society for Lactic Acid Bacteria. Universitas Udayana, Denpasar (2004)

[5] Suparno.: Ilmu dan Teknologi Pengolahan Daging. Gajah Mada University Press, Yogyakarta (1994)

[6] Tirtana, L.: Identifikasi Staphylococcus aureus Penyebab Mastitis Dengan Uji Fermentasi Mannitol dan Deteksi Produksi Asetoin Pada Sapi Perah di Wilayah Kerja Koprasi Usaha Tani Ternak Suka Makmur Grati Pasuruan. Skripsi. Universitas Airlangga, Surabaya (2007)

[7] Aryanta, W.R., Arihanta, M.B., \& Kartini, A.A.S.P.: Seleksi dan Pemanfaatan Bakteri Asam Laktat untuk Meningkatkan Mutu Sosis Terfermentasi Tradisional Bali. Laporan Penelitian Pusat Penelitian Universitas Udayana, Denpasar. (1994)

[8] Kartika, E. S., Khotimah., \& Yanti, A.H.: Deteksi Bakteri Indikator Keamanan Pangan Pada Sosis Daging Ayam Di Pasar Flamboyan Pontianak. Jurnal Protobiont. Vol. 3(2). pp. 111-119 (2014)

[9] Setiowati, W.E., \& Inanisantri.: Kajian Monitoring dan Surveilan Cemaran Mikroba Australian Institute of Food Science and Technology Incorporatyed (NSW Branch) (2011)

\section{TIDAK ADA PADA KUTIPAN}

Badan Standarisasi Nasional.: Standar Nasional Indonesia (SNI) 01-3820-1995. Tentang Sosis Daging, Jakarta (1995)

Pelczar, M.J. \& Reid, R.D.: Microbiology. Mc Graw Hill Co, New York (1979)

Semariyani, A.A. Made, I Wayan Sudiarta \& Luh Suriati.: Cita Rasa Pangan Tradisional Urutan Khas Bali Berbasis Daging Ayam. Universitas Warmadewa, Denpasar (2017) 
